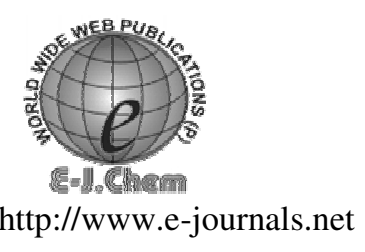

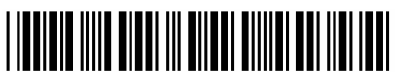

ISSN: 0973-4945; CODEN ECJHAO

E-Journal of Chemistry

Vol. 5, No.2, pp.385-394, April 2008

\title{
Analysis of Pressure-Volume Relationship for Bulk Metallic Glasses
}

\author{
H. K. RAI, A. K. MISRA, S. P. SHUKLA and A. K. PANDEY \\ Solid State Chemistry Lab, Deptt. of Chemistry \\ Sri J. N. (P. G.) College, Lucknow \\ anjani_withyou@yahoo.co.in
}

Received 18 September 2007; Accepted 19 October 2007

\begin{abstract}
Relationship between compression $\left(\mathrm{V} / \mathrm{V}_{0}\right)$ and pressure have been studied for five bulk metallic glasses (BMGs) viz. $\mathrm{Zr}_{41} \mathrm{Ti}_{14} \mathrm{Cu}_{12.5} \mathrm{Ni}_{10} \mathrm{Be}_{22.5}$, $\mathrm{Zr}_{41} \mathrm{Ti}_{14} \mathrm{Cu}_{12.5} \mathrm{Ni}_{9} \mathrm{Be}_{22.5} \mathrm{C}_{1}, \mathrm{Zr}_{48} \mathrm{Nb}_{8} \mathrm{Cu}_{12} \mathrm{Fe}_{8} \mathrm{Be}_{24},\left(\mathrm{Zr}_{0.59} \mathrm{Ti}_{0.06} \mathrm{Cu}_{0.22} \mathrm{Ni}_{0.13}\right)_{85.7} \mathrm{Al}_{14.3}$ and $\mathrm{SiO}_{2} \cdot \mathrm{TiO}_{2}$ in the compression ranges of $\mathrm{V} / \mathrm{V}_{0}=1.00$ to $\mathrm{V} / \mathrm{V}_{0}=0.10$. Six forms of equation of state reported in the literature have been used in the present study to calculate pressure corresponding to different values of compressions. The comparison of graph plotted between the logarithms of calculated value of pressure to logarithm of calculated value of compression $\left(\mathrm{V} / \mathrm{V}_{0}\right)$ reveals that the agreement of Brennan-Stacey equation of state (EOS) and Poirier-Tarantolla equation of state are not good. It has been found that the assumptions, on which these equations are based, do not satisfy well in case of given BMGs.
\end{abstract}

Keywords: BMGs, EOS, Metallic glasses, Pressure-Volume Relationship

\section{Introduction}

The equation of state of a solid plays an important role in condensed matter physics, geophysics and application ${ }^{1,2}$. However, little information about equation of state (EOS) is obtained for metallic glasses, because the measurements of equation of state have been impeded mainly by the inability to prepare bulk metallic glassy specimens. Studies on the equation of metallic glasses have been secant because of the inability to prepare bulk specimen $^{3}$. When a metal melt is cooled, one of the two events may occur, either crystallisation may take place at melting point or else melt will become more viscous below the melting point with decreasing temperature and may ultimately form amorphous solid i.e. metallic glasses. Thus metallic glassy state can be considered as the result of structural freezing of a liquid. The structure and interaction between atoms in metallic glasses are markedly different from those of ionic, covalent or metallic crystals. 
The BMG alloy is composed of five-six metallic components with large size difference in the atomic diameter and the glass from point of view of microstructural is considered as a frozen under cooled metal melt, thus the atomic arrangement is random close packing and the existence of free volume. However, The understanding of pressure effects on BMG's are still remain on a very qualitative level because of the lack of the qualitative properties of the compressed metallic glassy state under high pressure.

The derivation of equation of state of a thermodynamic system is based on the fundamental theorem which equates the negative of pressure to the isothermal volume derivative of a Helmholtz free energy function $\mathrm{F}^{4}$. The function $\mathrm{F}$ consists of two terms in case of solids, the first of which represents the potential energy of a non vibrating lattice, while the second owes its origin to the pressure of the thermal vibrations.

In present study, we consider six equation of state viz. Born-Mie $\operatorname{EOS}^{5}$, Vinet $\mathrm{EOS}^{6}$, Shanker EOS ${ }^{7}$, Murnaghan EOS ${ }^{8}$, Brennan-Stacey EOS ${ }^{9}$ and Poirier-Tarantola EOS ${ }^{10}$ to study the pressure volume relation for five different BMGs viz. $\mathrm{Zr}_{41} \mathrm{Ti}_{14} \mathrm{Cu}_{12.5} \mathrm{Ni}_{10} \mathrm{Be}_{22.5}$, $\mathrm{Zr}_{41} \mathrm{Ti}_{14} \mathrm{Cu}_{12.5} \mathrm{Ni}_{9} \mathrm{Be}_{22.5} \mathrm{C}_{1}, \mathrm{Zr}_{48} \mathrm{Nb}_{8} \mathrm{Cu}_{12} \mathrm{Fe}_{8} \mathrm{Be}_{24}, \mathrm{SiO}_{2} . \mathrm{TiO}_{2}$ and $\left(\mathrm{Zr}_{0.59} \mathrm{Ti}_{0.0} 6 \mathrm{Cu}_{0.22} \mathrm{Ni}_{0.13}\right)_{85.7} \mathrm{Al}_{14.3}$.

\section{Formulation for equation of state}

An equation of state can be derived from the volume derivative of lattice potential energy $y^{5,11}$

$$
\mathbf{P}=-\left(\frac{\mathbf{d W}}{\mathbf{d V}}\right)_{\mathrm{T}}
$$

where $\mathrm{W}$ for an ionic crystal can be written as the sum of electrostatic energy and short range overlap repulsive energy

$$
\mathrm{W}=-\alpha_{\mathrm{M}} \frac{\mathrm{Z}^{2} \mathrm{e}^{2}}{\mathrm{~V}^{1 / 3}}+\Phi(\mathrm{V})
$$

When we use an inverse power form for $\Phi$, such as $\left(\mathrm{aV}^{-\mathrm{n}}\right)$ we get the Born-Mie equation of state after eliminating the parameters " a" and " $\mathrm{n}$ " in terms of isothermal bulk modulus $\left(\mathrm{K}_{0}\right)$ and first pressure derivative of isothermal bulk modulus $\left(\mathrm{K}_{0}^{\prime}\right)$ at zero pressure. Thus, the Born-Mie equation of state $e^{5}$ becomes:

$$
P=\frac{3 K_{0}}{3 K_{0}-8}\left[\left(\frac{V}{V_{0}}\right)^{4 / 3-K_{0}^{\prime}}-\left(\frac{V}{V_{0}}\right)^{-4 / 3}\right]
$$

Vinet proposed a EOS on account of relating binding energy with inter atomic distances known as Vinet EOS $^{6}$, which may be expressed as

$$
\mathbf{P}=3 K_{0}(1-X) X^{-2} \exp [\eta(1-X)]
$$

where $\eta=\frac{3\left(K_{0}^{\prime}-1\right)}{2}$ and $X=\left(\frac{V}{V_{0}}\right)^{1 / 3}$

On the basis of Born lattice theory ${ }^{12}$ taking the volume derivative of short range force constant, Shanker obtained a equation of state known as Shanker $\operatorname{EOS}^{7}$ which are as

$$
P=\frac{\left[K_{0}\left(\frac{V}{V_{0}}\right)^{-4 / 3}\right]}{t}\left[\left(1-\frac{1}{t}+\frac{2}{t^{2}}\right)\{\exp (t y)-1\}+y\left(1+y-\frac{2}{t}\right) \exp (t y)\right]
$$

where $\mathbf{y}=\mathbf{1}-\frac{\mathbf{V}}{\mathbf{V}_{\mathbf{0}}}$ and $\mathbf{t}=\left(\mathbf{K}_{\mathbf{0}}^{\prime}-\frac{\mathbf{8}}{\mathbf{3}}\right)$ 
$\mathrm{K}_{0}$ is isothermal bulk modulus and $\mathrm{K}_{0}^{\prime}$ is the first derivative of isothermal bulk modulus at zero pressure. Using the free volume formula ${ }^{13}$ for the Grüneisen parameter $\gamma$ and assuming that the Gruneisen parameter $\gamma$ is proportional to volume, Brennan and Stacey obtained an $\operatorname{EOS}^{9}$ which is given as

$$
P=\frac{3 K_{0}\left(\frac{V}{V_{0}}\right)^{-4 / 3}}{\left(3 K_{0}^{\prime}-5\right)}\left[\exp \left\{\frac{\left(3 K_{0}^{\prime}-5\right)\left(1-\frac{V}{V_{0}}\right)}{3}\right\}-1\right]
$$

A simple EOS based on assumption according to which the isothermal bulk modulus $\mathrm{K}_{\mathrm{T}}$ depends linearly on pressure i.e.

$$
K_{T}=K_{0}+K_{0}^{\prime} \mathbf{P}
$$

Murnaghan gave an equation of state known as Murnaghan $\operatorname{EOS}^{8}$ which can be expressed as

$$
P=\frac{K_{0}}{K_{0}^{\prime}}\left[\left(\frac{V}{V_{0}}\right)^{-K_{0}^{\prime}}-1\right]
$$

Poirier and Tarantolla ${ }^{10}$ derived an equation similar to Birch EOS but define strain as $\mathrm{C}=\log \left(\mathrm{l}_{0} / \mathrm{l}\right)$ rather than Eulerian Strain $\mathrm{f}=1 / 2\left[\left(\mathrm{~V} / \mathrm{V}_{0}\right)^{-2 / 3}-1\right]$ used by Birch and give an EOS as

$$
P=K_{0}\left(\frac{V_{0}}{V}\right)\left[\ln \left(\frac{V_{0}}{V}\right)+\left\{\left(\frac{K_{0}^{\prime}-2}{2}\right)\right\}\left\{\ln \left(\frac{V_{0}}{V}\right)\right\}^{2}\right]
$$

\section{Results and Discussion}

The pressure have been calculated at different compression ranges (from $\mathrm{V} / \mathrm{V}_{0}=1.0$ to 0.01 ) for five different BMGs viz. $\mathrm{Zr}_{41} \mathrm{Ti}_{14} \mathrm{Cu}_{12.5} \mathrm{Ni}_{10} \mathrm{Be}_{22.5}, \quad \mathrm{Zr}_{41} \mathrm{Ti}_{14} \mathrm{Cu}_{12.5} \mathrm{Ni}_{9} \mathrm{Be}_{22.5} \mathrm{C}_{1}$, $\mathrm{Zr}_{48} \mathrm{Nb}_{8} \mathrm{Cu}_{12} \mathrm{Fe}_{8} \mathrm{Be}_{24}, \quad\left(\mathrm{Zr}_{0.59} \mathrm{Ti}_{0.06} \mathrm{Cu}_{0.22} \mathrm{Ni}_{0.13}\right)_{85.7} \mathrm{Al}_{14.3}$ and $\mathrm{SiO}_{2} . \mathrm{TiO}_{2}$ using six different equation of states viz. Born-Mie EOS, Vinet EOS, Shanker EOS, Murnaghan EOS, BrennanStacey EOS and Poirier-Tarantola EOS from equation (3-8). The calculated values are displayed in Table 2-6. The input value of isothermal bulk modulus $\mathrm{K}_{0}$ and its first pressure derivative $\left(\mathrm{K}_{0}^{\prime}\right)$ at zero pressure are taken from the literature ${ }^{14}$, displayed in Table 1 . The logarithmic values of calculated pressure obtained by different EOS have been plotted against the logarithmic values of unit cell volume ratio $\left(\mathrm{V} / \mathrm{V}_{0}\right)$ and shown graphically, displayed in Fig. (1-5). The results thus obtained show very interesting pattern i.e. the values of pressure of $\mathrm{Zr}_{41} \mathrm{Ti}_{14} \mathrm{Cu}_{12.5} \mathrm{Ni}_{10} \mathrm{Be}_{22.5}, \quad \mathrm{Zr}_{41} \mathrm{Ti}_{14} \mathrm{Cu}_{12.5} \mathrm{Ni}_{9} \mathrm{Be}_{22.5} \mathrm{C}_{1}, \quad \mathrm{Zr}_{48} \mathrm{Nb}_{8} \mathrm{Cu}_{12} \mathrm{Fe}_{8} \mathrm{Be}_{24}$ and $\left(\mathrm{Zr}_{0.59} \mathrm{Ti}_{0.06} \mathrm{Cu}_{0.22} \mathrm{Ni}_{0.13}\right)_{85.7} \mathrm{Al}_{14.3}$, shows non linear characteristic [Fig. (1-4)], where as for $\mathrm{SiO}_{2} \mathrm{TiO}_{2}$ glass appears complex characteristic [Fig. (5)]. The different responses to pressure of silicate and metallic glasses are due to completely different structural characteristic of BMGs (random close packing atomic configuration) and oxide glasses (continuous-random networks ). Oxide glass is a covalent-bonded glass with a significant spread in $\mathrm{Si}-\mathrm{O}-\mathrm{Si}$ bond angles. Under high pressure, the change of the bond angles between atoms in oxide glass leads to negative pressure-dependent velocities. For BMGs with random close packing atomic structure, however, the nature of metallic bond is retained in the BMGs, although atomic long range order is lacking. In the transition process from the glass to crystalline state, there is no significant change of the nearest-neighbour atoms and the distance between atoms. However, the small change of the volume can sensitively induce changes in the electron configuration, atomic interaction force and the relative flow between atoms. So BMGs have a large shear modulus change upon crystallization. 
Table 1. The input values of isothermal bulk modulus $\left(\mathrm{K}_{0}\right) \&$ its first pressure derivative $\left(\mathbf{K}_{\mathbf{0}}^{\prime}\right)$ at zero pressure ${ }^{14}$

\begin{tabular}{cccc}
\hline S.No. & Sample & $\mathrm{K}_{0}(\mathrm{GPa})$ & $\mathbf{K}_{\mathbf{0}}^{\prime}(\mathrm{GPa})$ \\
\hline 1. & $\mathrm{Zr}_{41} \mathrm{Ti}_{14} \mathrm{Cu}_{12.5} \mathrm{Ni}_{10} \mathrm{Be}_{22.5}$ & 114.10 & 4.06 \\
2. & $\mathrm{Zr}_{41} \mathrm{Ti}_{14} \mathrm{Cu}_{12.5} \mathrm{Ni}_{9} \mathrm{Be}_{22.5} \mathrm{C}_{1}$ & 107.30 & 3.94 \\
3. & $\mathrm{Zr}_{48} \mathrm{Nb}_{8} \mathrm{Cu}_{12} \mathrm{Fe}_{8} \mathrm{Be}_{24}$ & 113.60 & 4.10 \\
4. & $\left(\mathrm{Zr}_{0.59} \mathrm{Ti}_{0.06} \mathrm{Cu}_{0.22} \mathrm{Ni}_{0.13}\right)_{85.7} \mathrm{Al}_{14.3}$ & 112.60 & 4.34 \\
5. & $\mathrm{SiO}_{2 .} \mathrm{TiO}_{2}$ & 34.20 & -4.02 \\
\hline
\end{tabular}

Table 2. Calculated values of pressure $(\mathrm{P})$ in $\mathrm{GPa}$ as a function of $\mathrm{V} / \mathrm{V}_{0}$ at different compressions using different equation of state from equations (3-8) for bulk metallic glass " $\mathrm{Zr}_{41} \mathrm{Ti}_{14} \mathrm{Cu}_{12.5} \mathrm{Ni}_{10} \mathrm{Be}_{22.5}$ "

\begin{tabular}{|c|c|c|c|c|c|c|}
\hline $\mathrm{V} / \mathrm{V}_{0}$ & $\begin{array}{c}\text { P (Gpa) } \\
\text { Born-Mie } \\
\text { EOS } \\
(3)\end{array}$ & $\begin{array}{c}\mathrm{P}(\mathrm{GPa}) \\
\text { Brennan- } \\
\text { Stacey EOS } \\
(6)\end{array}$ & $\begin{array}{c}\mathrm{P}(\mathrm{GPa}) \\
\text { Poirer - } \\
\text { Tarantola } \\
\text { EOS (8) }\end{array}$ & $\begin{array}{l}\mathrm{P}(\mathrm{GPa}) \\
\text { Murnaghan } \\
\text { EOS } \\
(7)\end{array}$ & $\begin{array}{c}\mathrm{P}(\mathrm{GPa}) \\
\text { Vinet } \\
\text { EOS } \\
(4)\end{array}$ & $\begin{array}{c}\mathrm{P}(\mathrm{GPa}) \\
\text { Shanker } \\
\text { EOS } \\
(5)\end{array}$ \\
\hline 1 & 0.00 & 0.00 & 0.00 & 0.00 & 0.00 & 0.00 \\
\hline 0.9 & 14.90 & 15.00 & 13.33 & 14.83 & 14.85 & 14.86 \\
\hline 0.8 & 40.20 & 41.42 & 31.31 & 39.40 & 39.56 & 39.64 \\
\hline 0.7 & 84.78 & 91.44 & 55.65 & 80.54 & 81.39 & 81.58 \\
\hline 0.6 & 167.80 & 195.36 & 88.94 & 151.11 & 154.49 & 154.37 \\
\hline 0.5 & 335.43 & 440.21 & 135.53 & 277.23 & 288.78 & 285.95 \\
\hline 0.4 & 717.40 & 1130.16 & 203.18 & 517.87 & 554.99 & 539.59 \\
\hline 0.3 & 1772.00 & 3694.22 & 307.65 & 1029.48 & 1150.21 & 1083.46 \\
\hline 0.2 & 5880.19 & 19264.62 & 487.90 & 2355.43 & 2790.98 & 2502.43 \\
\hline 0.1 & 41736.39 & 321318.40 & 885.49 & 7816.41 & 9944.05 & 8373.97 \\
\hline
\end{tabular}

Table 3. Calculated values of pressure $(\mathrm{P})$ in $\mathrm{GPa}$ as a function of $\mathrm{V} / \mathrm{V}_{0}$ at different compressions using different equation of state from equations (3-8) for bulk metallic glass " $\mathrm{Zr}_{41} \mathrm{Ti}_{14} \mathrm{Cu}_{12.5} \mathrm{Ni}_{9} \mathrm{Be}_{22.5} \mathrm{C}_{1} "$

\begin{tabular}{ccccccc}
\hline & $\begin{array}{c}\mathrm{P}(\mathrm{Gpa}) \\
\text { Born-Mie } \\
\text { EOS } \\
\text { V/V }\end{array}$ & $\begin{array}{c}\mathrm{P}(\mathrm{GPa}) \\
\text { Brennan- } \\
\text { Stacey EOS } \\
(3)\end{array}$ & $\begin{array}{c}\mathrm{P}(\mathrm{GPa}) \\
\text { Poirer }- \\
\text { Tarantola } \\
\text { EOS }(8)\end{array}$ & $\begin{array}{c}\mathrm{P}(\mathrm{GPa}) \\
\text { Murnaghan } \\
\text { EOS } \\
(7)\end{array}$ & $\begin{array}{c}\mathrm{P}(\mathrm{GPa}) \\
\text { Vinet } \\
\text { EOS } \\
(4)\end{array}$ & $\begin{array}{c}\mathrm{P}(\mathrm{GPa}) \\
\text { Shanker EOS } \\
(5)\end{array}$ \\
\hline 1 & 0.00 & 0.00 & 0.00 & 0.00 & 0.00 & 0.00 \\
0.9 & 13.92 & 14.01 & 12.46 & 13.87 & 13.88 & 13.89 \\
0.8 & 37.30 & 38.38 & 29.14 & 36.59 & 36.74 & 36.81 \\
0.7 & 77.97 & 83.83 & 51.54 & 74.28 & 75.06 & 75.23 \\
0.6 & 152.68 & 176.68 & 82.02 & 138.35 & 141.38 & 141.31 \\
0.5 & 301.17 & 391.13 & 124.46 & 251.86 & 261.99 & 259.70 \\
0.4 & 633.01 & 981.02 & 185.84 & 466.66 & 498.55 & 486.02 \\
0.3 & 1526.39 & 3106.58 & 280.29 & 919.81 & 1021.20 & 967.50 \\
0.2 & 4882.82 & 15468.90 & 442.70 & 2085.93 & 2441.72 & 2214.61 \\
0.1 & 32357.19 & 238140.61 & 799.71 & 6858.75 & 8518.94 & 7342.44 \\
\hline
\end{tabular}


Table 4. Calculated values of pressure $(\mathrm{P})$ in $\mathrm{GPa}$ as a function of $\mathrm{V} / \mathrm{V}_{0}$ at different compressions using different equation of state from equations $(3-12,15,16)$ for bulk metallic glass " $\mathrm{Zr}_{48} \mathrm{Nb}_{8} \mathrm{Cu}_{12} \mathrm{Fe}_{8} \mathrm{Be}_{24} "$

\begin{tabular}{ccccccc}
\hline & $\begin{array}{c}\mathrm{P}(\mathrm{Gpa}) \\
\text { Born-Mie } \\
\text { EOS } \\
\text { V/V }\end{array}$ & $\begin{array}{c}\mathrm{P}(\mathrm{GPa}) \\
\text { Brennan- } \\
\text { Stacey EOS } \\
(3)\end{array}$ & $\begin{array}{c}\mathrm{P}(\mathrm{GPa}) \\
\text { Poirer } \\
\text { Tarantola } \\
\text { EOS }(8)\end{array}$ & $\begin{array}{c}\text { P }(\mathrm{GPa}) \\
\text { Murnaghan } \\
\text { EOS } \\
(7)\end{array}$ & $\begin{array}{c}\text { P }(\mathrm{GPa}) \\
\text { Vinet } \\
\text { EOS } \\
(4)\end{array}$ & $\begin{array}{c}\text { P (GPa) } \\
\text { Shanker } \\
\text { EOS } \\
(5)\end{array}$ \\
\hline 1 & 0.00 & 0.00 & 0.00 & 0.00 & 0.00 & 0.00 \\
0.9 & 14.87 & 14.97 & 13.30 & 14.80 & 14.81 & 14.82 \\
0.8 & 40.22 & 41.46 & 31.29 & 39.40 & 39.56 & 39.64 \\
0.7 & 85.08 & 91.86 & 55.70 & 80.74 & 81.59 & 81.78 \\
0.6 & 169.03 & 197.22 & 89.16 & 151.88 & 155.30 & 155.17 \\
0.5 & 339.51 & 447.21 & 136.06 & 279.42 & 291.18 & 288.24 \\
0.4 & 730.67 & 1157.66 & 204.24 & 523.48 & 561.58 & 545.52 \\
0.3 & 1820.43 & 3826.90 & 309.68 & 1043.80 & 1168.69 & 1098.75 \\
0.2 & 6121.01 & 20285.49 & 491.80 & 2395.77 & 2850.62 & 2545.88 \\
0.1 & 44529.49 & 348069.39 & 893.96 & 7976.40 & 10232.17 & 8547.63 \\
\hline
\end{tabular}

Table 5. Calculated values of pressure $(\mathrm{P})$ in $\mathrm{GPa}$ as a function of $\mathrm{V} / \mathrm{V}_{0}$ at different compressions using different equation of state from equations (3-8) for bulk metallic glass " $\left(\mathrm{Zr}_{0.59} \mathrm{Ti}_{0.06} \mathrm{Cu}_{0.22} \mathrm{Ni}_{0.13}\right)_{85.7} \mathrm{Al}_{14.3} "$

\begin{tabular}{ccccccc}
\hline & $\begin{array}{c}\mathrm{P}(\mathrm{Gpa}) \\
\text { Born-Mie } \\
\text { EOS } \\
\text { V/V }\end{array}$ & $\begin{array}{c}\mathrm{P}(\mathrm{GPa}) \\
\text { Brennan- } \\
\text { Stacey EOS } \\
(6)\end{array}$ & $\begin{array}{c}\mathrm{P}(\mathrm{GPa}) \\
\text { Poirer } \\
\text { Tarantola } \\
\text { EOS }(8)\end{array}$ & $\begin{array}{c}\mathrm{P}(\mathrm{GPa}) \\
\text { Murnagha } \\
\text { n EOS } \\
(7)\end{array}$ & $\begin{array}{c}\mathrm{P}(\mathrm{GPa}) \\
\text { Vinet } \\
\text { EOS } \\
(4)\end{array}$ & $\begin{array}{c}\mathrm{P}(\mathrm{GPa}) \\
\text { Shanker } \\
\text { EOS } \\
(5)\end{array}$ \\
\hline 1 & 0.00 & 0.00 & 0.00 & 0.00 & 0.00 & 0.00 \\
0.9 & 14.93 & 15.04 & 13.33 & 14.86 & 14.87 & 14.88 \\
0.8 & 41.03 & 42.41 & 31.70 & 40.11 & 40.26 & 40.35 \\
0.7 & 88.45 & 96.13 & 56.96 & 83.41 & 84.28 & 84.51 \\
0.6 & 179.83 & 212.51 & 91.98 & 159.41 & 163.05 & 162.92 \\
0.5 & 371.87 & 500.49 & 141.49 & 298.21 & 311.35 & 307.82 \\
0.4 & 831.44 & 1361.79 & 214.03 & 568.63 & 613.16 & 593.10 \\
0.3 & 2184.18 & 4816.18 & 326.95 & 1154.96 & 1308.03 & 1217.18 \\
0.2 & 7962.64 & 28156.24 & 523.21 & 2702.36 & 3291.29 & 2875.65 \\
0.1 & 67353.28 & 572306.80 & 959.25 & 9178.20 & 12349.52 & 9850.56 \\
\hline
\end{tabular}

Another remarkable characteristic is observed that the variation in value of pressure from compression range $\mathrm{V} / \mathrm{V}_{0}=1.0$ to 0.4 are minimum but as the compression increases, variation in the values of pressure also increases. Pressure $\mathrm{P} v s \quad \mathrm{~V} / \mathrm{V}_{0}$ relation for $\mathrm{Zr}_{41} \mathrm{Ti}_{14} \mathrm{Cu}_{12.5} \mathrm{Ni}_{10} \mathrm{Be}_{22.5}, \quad \mathrm{Zr}_{41} \mathrm{Ti}_{14} \mathrm{Cu}_{12.5} \mathrm{Ni}_{9} \mathrm{Be}_{22.5} \mathrm{C}_{1}, \quad \mathrm{Zr}_{48} \mathrm{Nb}_{8} \mathrm{Cu}_{12} \mathrm{Fe}_{8} \mathrm{Be}_{24}, \quad$ and $\left(\mathrm{Zr}_{0.59} \mathrm{Ti}_{0.06} \mathrm{Cu}_{0.22} \mathrm{Ni}_{0.13}\right)_{85.7} \mathrm{Al}_{14.3}$ are almost same with slight variation upto $\mathrm{V} / \mathrm{V}_{0}=0.5$ but as the compression increases, variation in pressure gradually increases and after $\mathrm{V} / \mathrm{V}_{0}=0.3$ it increases abruptly which is crystal clear from the Fig. (1-4). 
Table 6. Calculated values of pressure (P) in $\mathrm{GPa}$ as a function of $\mathrm{V} / \mathrm{V}_{0}$ at different compressions using different equation of state from equations (3-8) for bulk metallic glass " $\mathrm{SiO}_{2} \cdot \mathrm{TiO}_{2}$ "

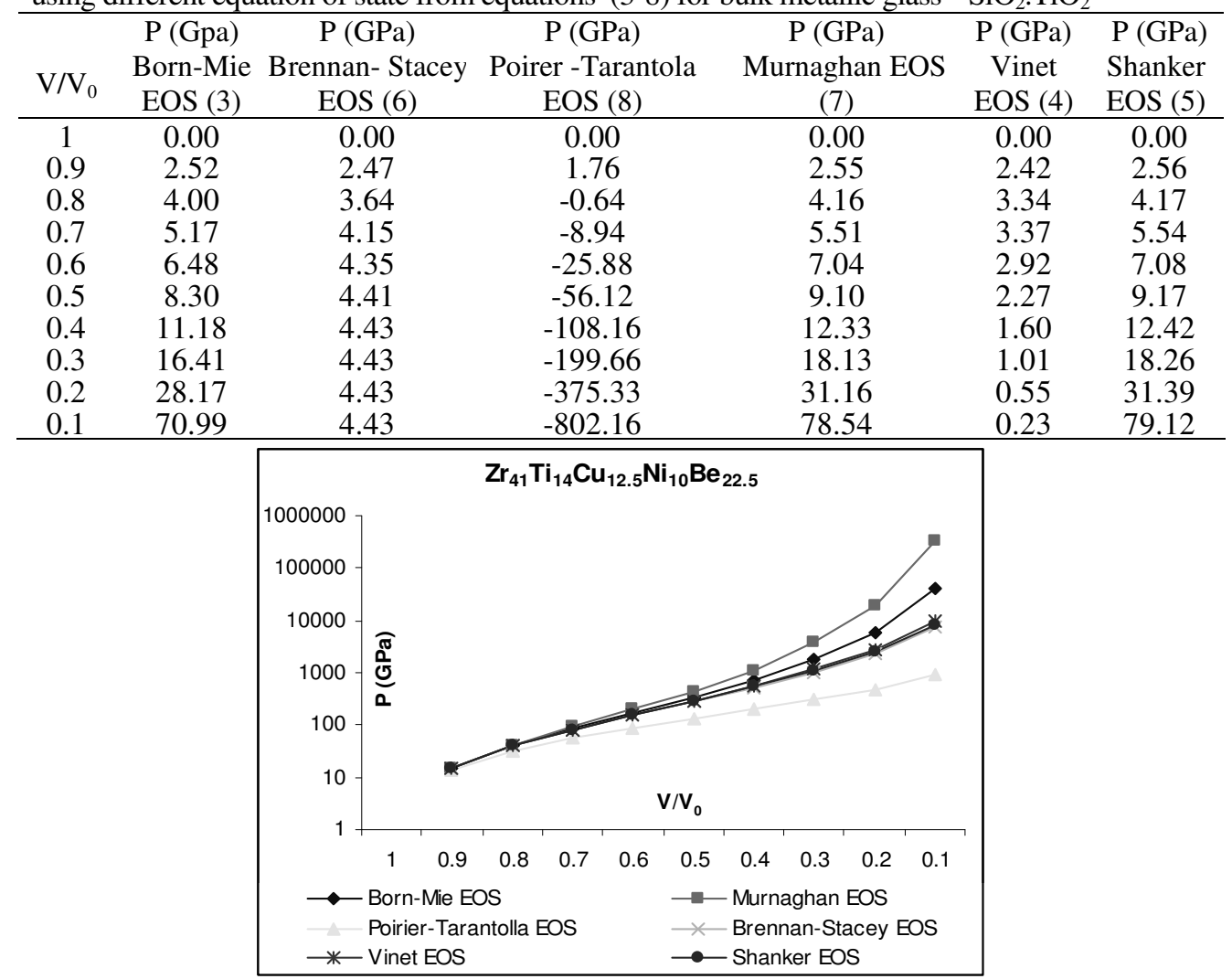

Figure 1. The logarithmic graph between calculated values of pressure $(\mathrm{P})$ against $\mathrm{V} / \mathrm{V}_{0}$ of bulk metallic glass " $\mathrm{Zr}_{41} \mathrm{Ti}_{14} \mathrm{Cu}_{12.5} \mathrm{Ni}_{10} \mathrm{Be}_{22.5}$ " using different equation of state from equations (3-8)

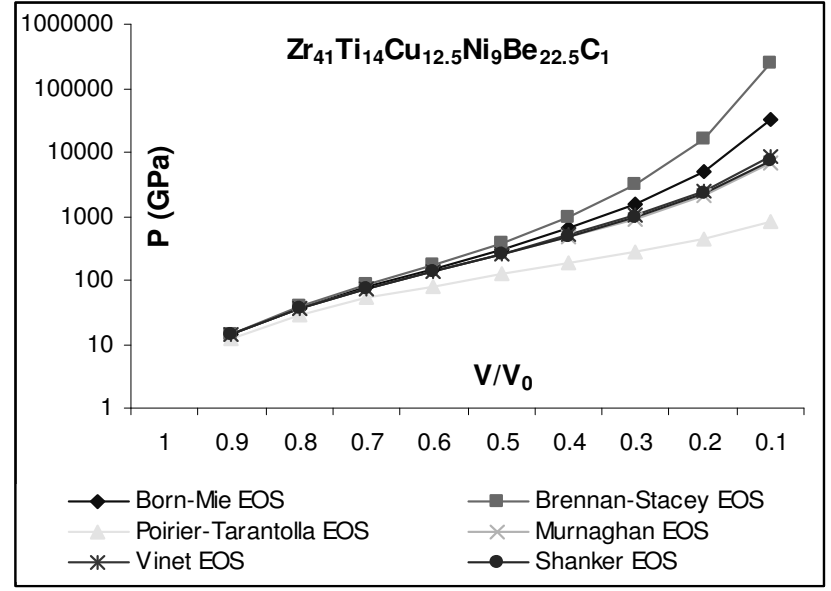

Figure 2. The logarithmic graph between calculated values of pressure $(\mathrm{P})$ against $\mathrm{V} / \mathrm{V}_{0}$ of bulk metallic glass" $\mathrm{Zr}_{41} \mathrm{Ti}_{14} \mathrm{Cu}_{12.5} \mathrm{Ni}_{9} \mathrm{Be}_{22.5} \mathrm{C}_{1}$ " using different equation of state from equations (3-8). 


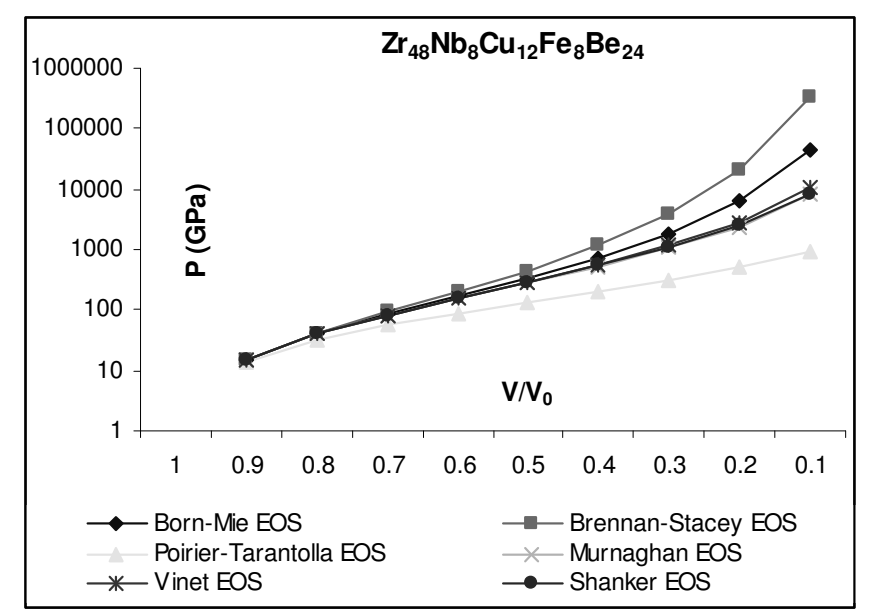

Figure 3. The logarithmic graph between calculated values of pressure $(\mathrm{P})$ against $\mathrm{V} / \mathrm{V}_{0}$ of bulk metallic glass " $\mathrm{Zr}_{48} \mathrm{Nb}_{8} \mathrm{Cu}_{12} \mathrm{Fe}_{8} \mathrm{Be}_{24}$ " using different equation of state from equations (3-8).

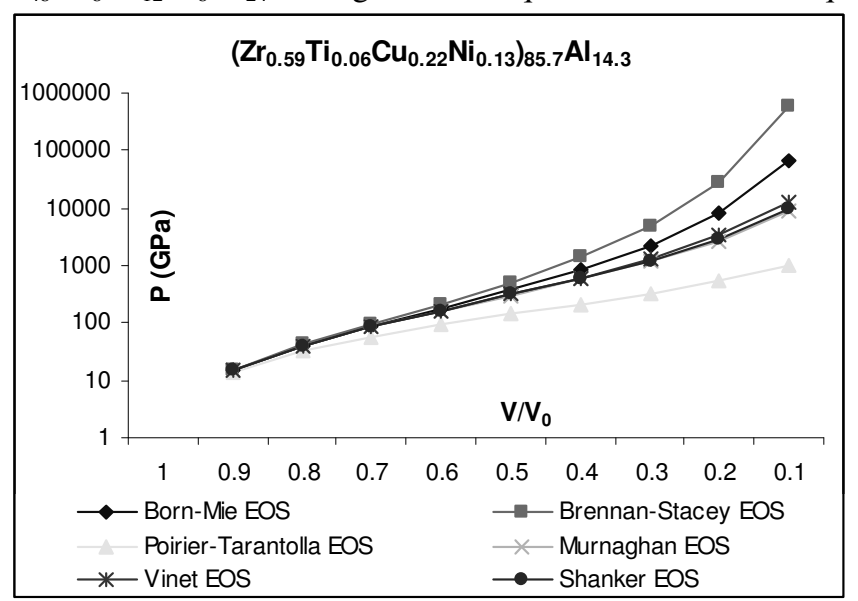

Figure 4. The logarithmic graph between calculated values of pressure $(\mathrm{P})$ against $\mathrm{V} / \mathrm{V}_{0}$ of bulk metallic glass " $\left(\mathrm{Zr}_{0.59} \mathrm{Ti}_{0.06} \mathrm{Cu}_{0.22} \mathrm{Ni}_{0.13}\right)_{85.7} \mathrm{Al}_{14.3}$ " using different equation of state from equations (3-8).

When we consider about the success of equation of state derived from certain scientists, we have observed that the four equation of state viz. Born-Mie EOS, Vinet EOS, Shanker EOS and Murnaghan EOS, show very good agreement with each other except Brennan-Stacey and Poirier-Tarantola EOS. It is observed that one equation of state shows deviation in upward direction, where as other shows a linear type projection. Now the question arises, why both these equations of state show a variation of marked difference.

Brennan-Stacey EOS is based on assumption that Grüneisen parameter is proportional to volume and equation is obtained on account of free volume formula. The metallic crystals have a packed arrangement, where as BMGs have random close packing with the existence of free volume. Due to this reason Brennan EOS in case of bulk metallic glasses fails hopelessly. 
The Poirier-Tarantola proposed a equation of state derived using Hencky logarithmic strain $^{15}$ equivalent to the Eulerian strain for small strain and better behaved for large strain. The reference strain is neither the initial nor the final configuration, but the instantaneous configuration of the body being deformed. In uniaxial deformation as the instantaneous volume $(\mathrm{V})$ of the body is increased by an infinitesimally small increment $\mathrm{dV}$, the ratio $(\mathrm{dV} / \mathrm{V})$ is considered as an increment of the current state of strain

$$
\mathrm{dE}=(\mathrm{dV} / \mathrm{V})
$$

When the solid goes from volume $\mathrm{V}_{0}$ to $\mathrm{V}$ the total finite strain or normal strain also called the Hencky measure of strain.

$$
\mathrm{E}_{\mathrm{H}}=(1 / 3) \log \left(\mathrm{V} / \mathrm{V}_{0}\right)
$$

It has been observed that Hencky strain is as a function of the ratio $\left(\mathrm{V}_{0} / \mathrm{V}\right)$ and in this way what we find that as the compression increases this potential deviates from other potential and successively it shows a pseudo linear characteristic in Fig. (1-4). In $\mathrm{SiO}_{2}$. $\mathrm{TiO}_{2}$ glass (Fig.5), the three potentials shows linear characteristic where two potentials Vinet and Poirier-Tarantola EOS shows non linear characteristic. The conclusion is very interesting and it requires a critical and comprehensive study for further research work.

For comparison, the compression against pressure curves of $\mathrm{Zr}, \mathrm{Ti}, \mathrm{Cu}, \mathrm{Ni}, \mathrm{Be}$ and $\mathrm{C}^{(16)}$ are also plotted with their corresponding BMGs, displayed in Fig.(6-7). The compression curves of all the BMGs are interposed among their metallic components, e.g., the compression curve $\mathrm{Zr}$-based BMGs are interposed among their components $\mathrm{Zr}, \mathrm{Ti}, \mathrm{Be}$, $\mathrm{Ni}, \mathrm{Al}$ and $\mathrm{Cu}$. This indicates that the compression curves of the BMGs have a correlation with that of their metallic components and exhibit a roughly average result of these elements. The compressibility of a solid is determined by the nature of the interatomic potential and the atomic configurations and thus afore mentioned results imply that the short-range order structure of the BMGs has a close correlation with the atomic configurations in their metallic components. Also the BMGs exhibit small volume changes upon pressure compared with oxide glasses, indicating that the BMGs have similar atomic close-packed configurations with elements and markedly different microstructure and properties from oxide glasses.

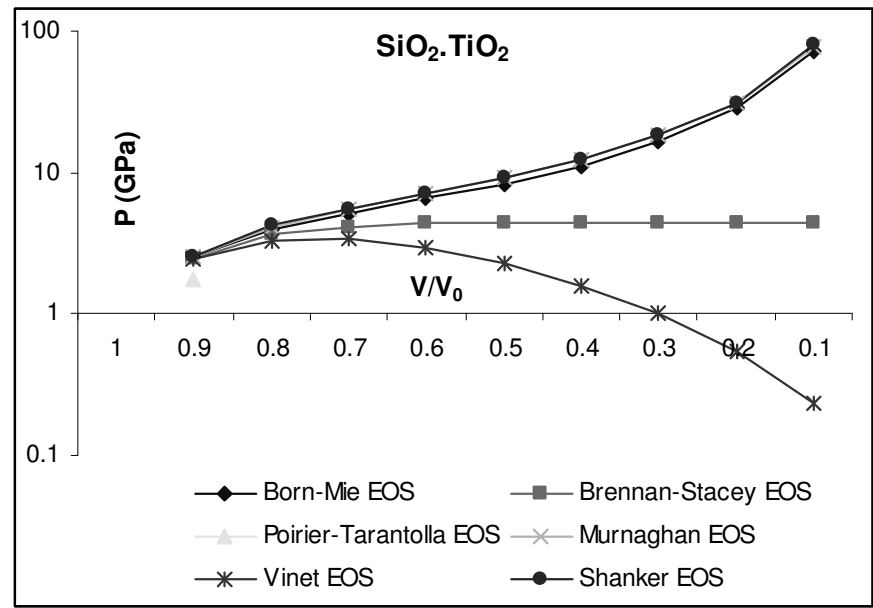

Figure 5. The logarithmic graph between calculated values of pressure $(\mathrm{P})$ against $\mathrm{V} / \mathrm{V}_{0}$ of bulk metallic glass " $\mathrm{SiO}_{2} \mathrm{TiO}_{2}$ " using different equation of state from equations (3-8) 


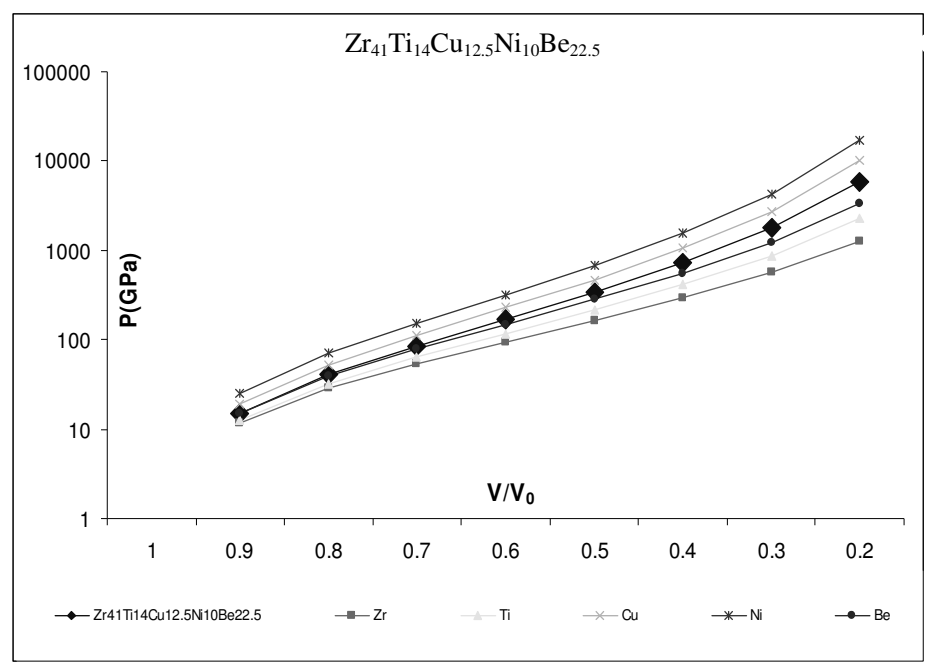

Figure 6. The logarithmic graph between calculated values of pressure $(\mathrm{P})$ against $\mathrm{V} / \mathrm{V}_{0}$ of crystalline component bulk of metallic glass " $\mathrm{Zr}_{41} \mathrm{Ti}_{14} \mathrm{Cu}_{12.5} \mathrm{Ni}_{10} \mathrm{Be}_{22.5}$ " and there metallic components using equation of state from equation (3)

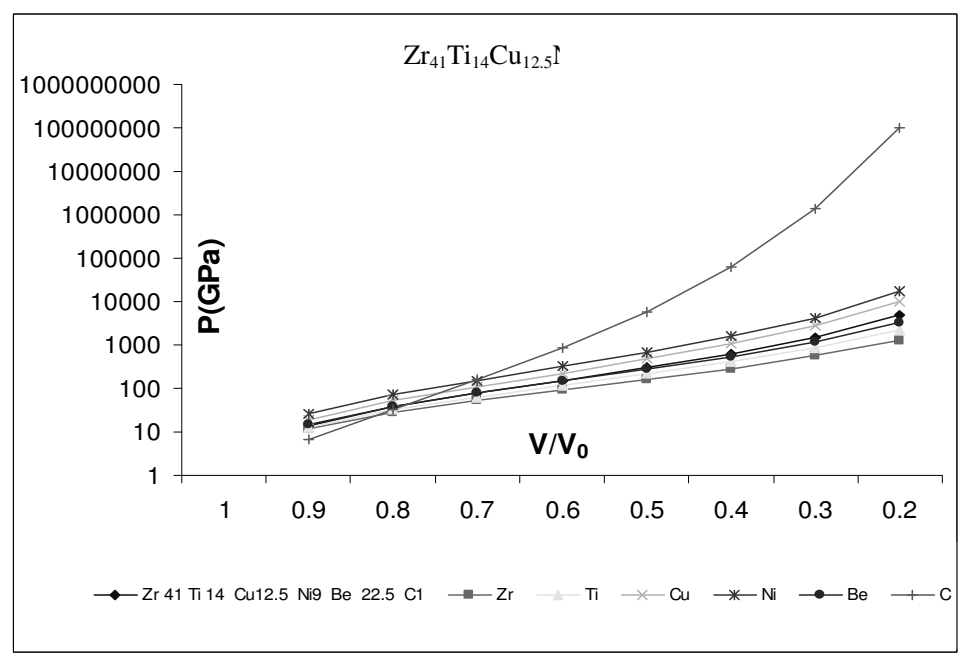

Figure 7. The logarithmic graph between calculated values of pressure $(\mathrm{P})$ against $\mathrm{V} / \mathrm{V}_{0}$ of crystalline component bulk of metallic glass " $\mathrm{Zr}_{41} \mathrm{Ti}_{14} \mathrm{Cu}_{12.5} \mathrm{Ni}_{9} \mathrm{Be}_{22.5} \mathrm{C}_{1}$ " and there metallic components using equation of state from equation (3)

\section{References}

1. Bridgman P W, Proc. Am. Acad. Arts Sci., 1942, 74, 425,

2. Vinet P, Smith J R, Ferranate J and Rose J H, J.Phys C: Solid State Physics, 1986, 19, L467,

3. M X Pan, W H Wang, D Q Zhao, Z X Bao, W X Zhang and S Z Zhang, J. Phys. Condense Matter, 2002, 14, 5665,

4. Trivedi G and Goyal S C, Ind. J. Pure Appl. Phys., 2001, 39, 361, 
5. Anderson O L, J. Geophys. Res., 1970, 75, 2719,

6. Vinet P, Smith J R, Ferranate J and Rose J H, J. Geophys. Res., 1987, 92, 9319,

7. Shanker J, Kushwah S S and Kumar P, Physica B, 1997, 239, 337,

8. Murnaghan F D, Proc. Acad. Science (USA), 1944, 30, 244,

9. Brennan B J and Stacey F D, J. Geophys. Res.,1979, 84, 5535,

10. Poirier J P and Tarantola A, Phys. of Earth and Planetary Interiors, 1998, 109, 1,

11. Roberts R W and Smith C S, J. Phys. Chem. Solids, 1970, 31, 619,

12. Born $\mathrm{M}$ and huang $\mathrm{K}$, Dynamical theory of crystal lattice (Clarendon press, oxford ), 1954

13. Vaschenkov Y A and Zubarev V N, Sov. Phys. Solid State, 1963, 5, 653,

14. Wang W H, Wen P, Wang L M, Zhang Y, Pan M X, Zhao D Q and Wang R J, Appl. Phys. Lett., 2001, 79, 24,

15. Ronald E G, Oguz G and Russell J H, American mineralogists, 2000, 85, 338,

16. Wein P and Wnag R J, J. Mater. Res., 2002, 17, 7, 


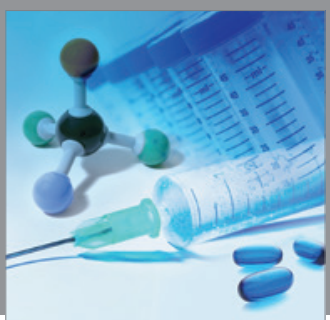

International Journal of

Medicinal Chemistry

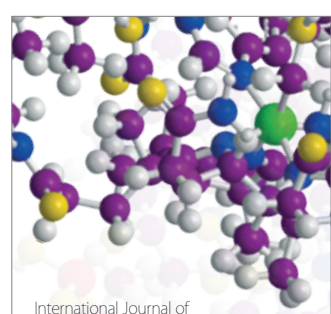

Carbohydrate Chemistry

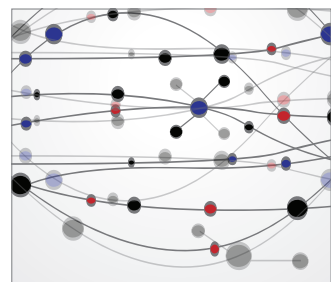

The Scientific World Journal
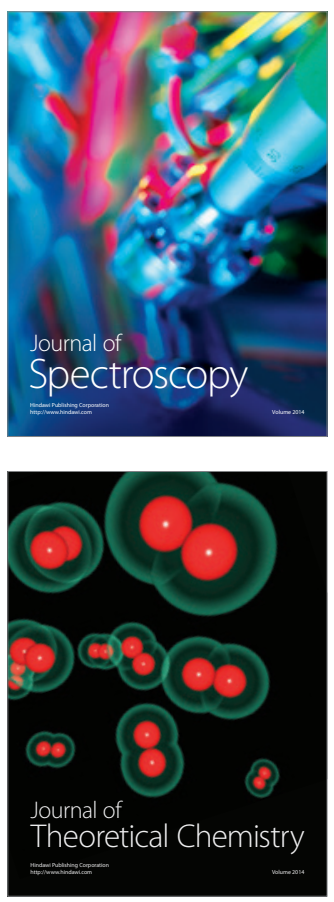
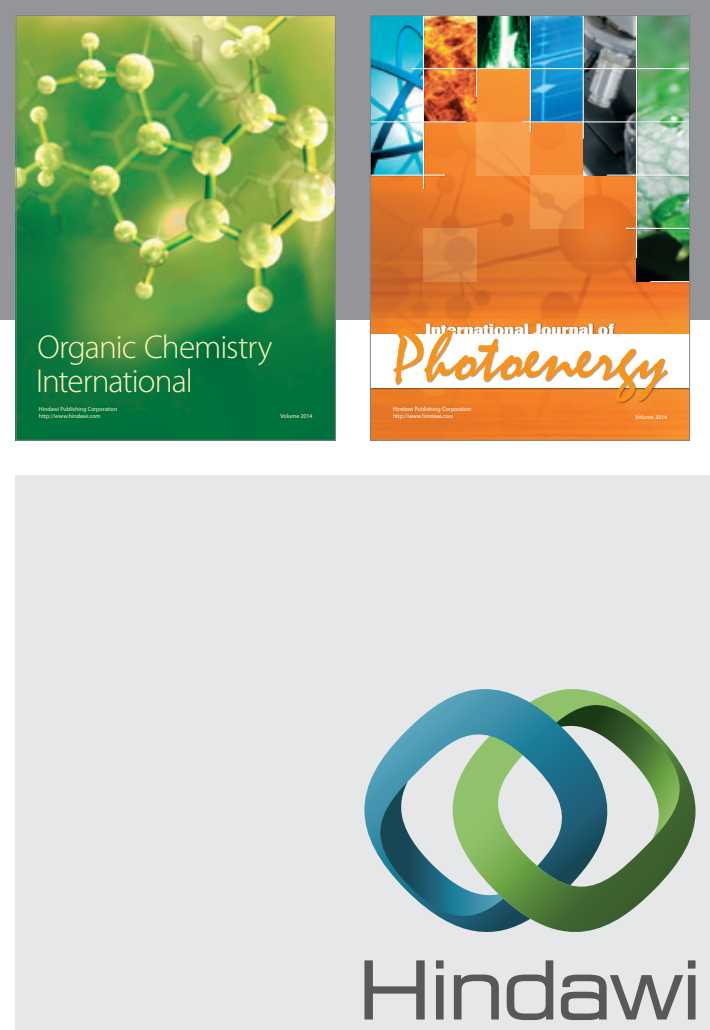

Submit your manuscripts at

http://www.hindawi.com
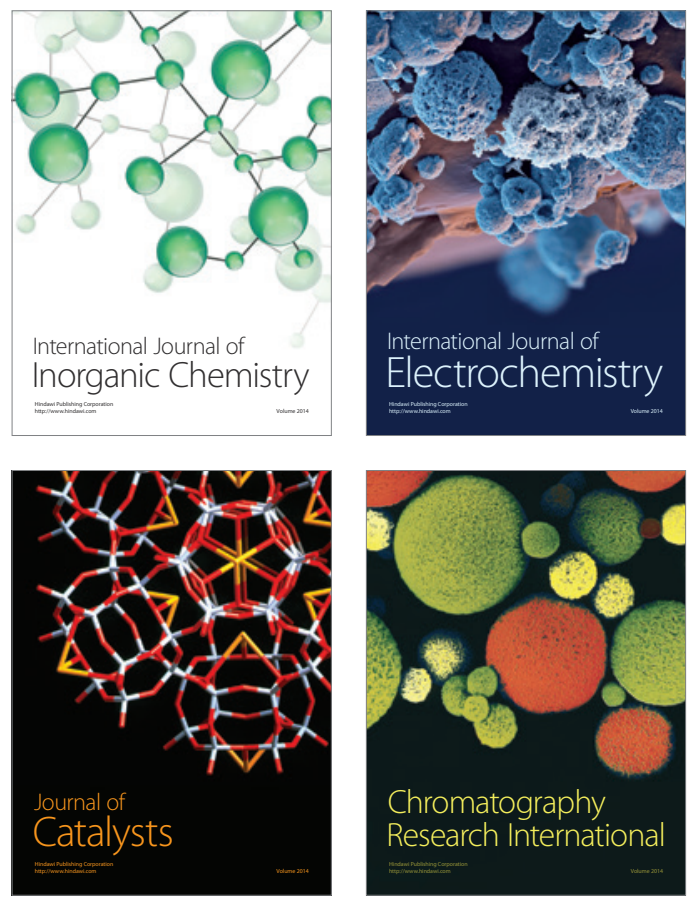
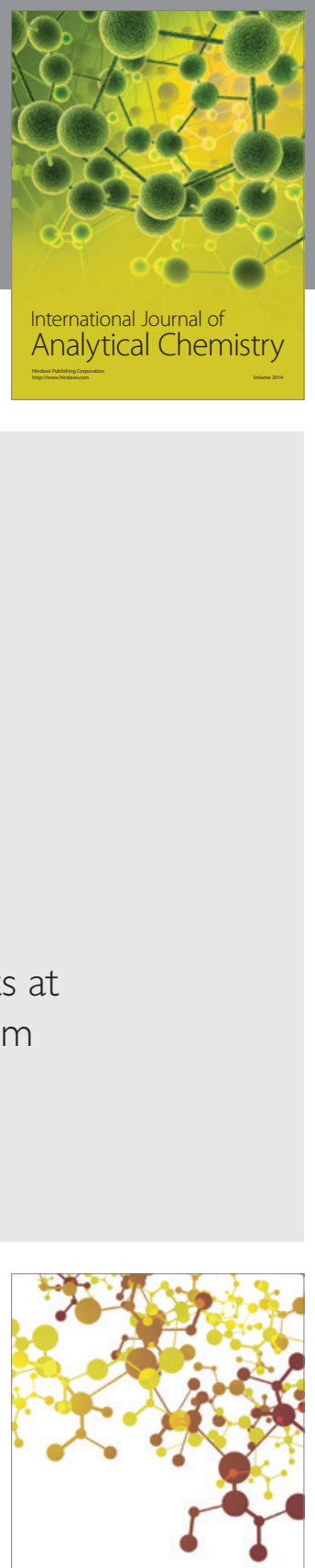

Journal of

Applied Chemistry
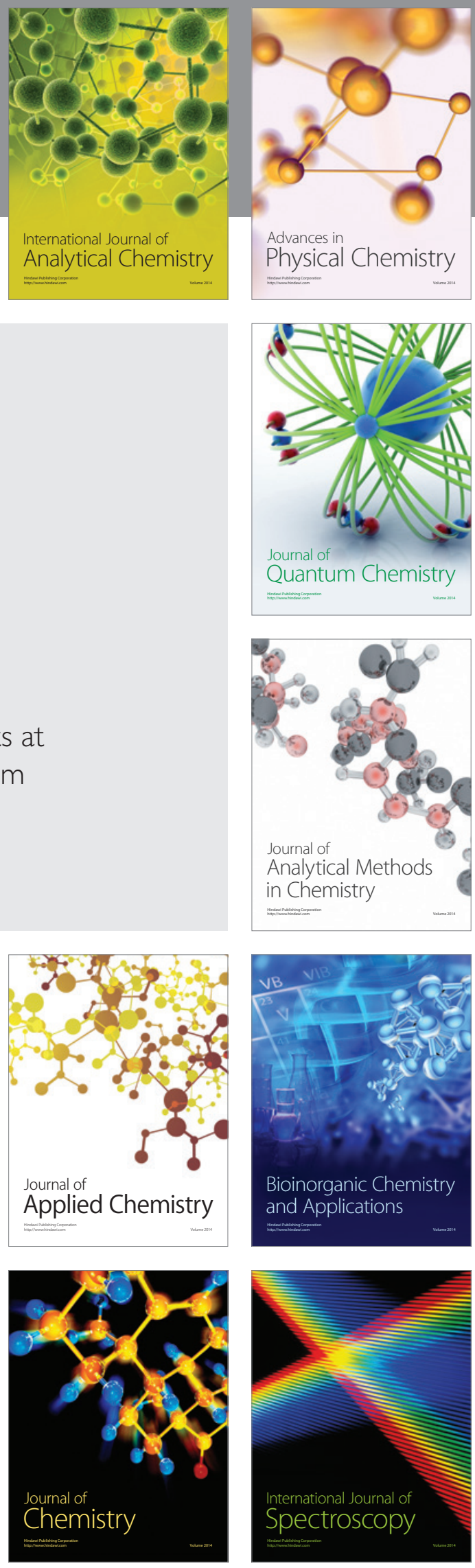